„Kwartalnik Filmowy” nr 109 (2020)

ISSN: 0452-9502 (Print) ISSN: 2719-2725 (Online)

https://doi.org/10.36744/kf.273

(C) Creative Commons BY-NC-ND 4.0

Krzysztof Loska

Uniwersytet Jagielloński

https://orcid.org/oooo-0003-4078-798X_

\title{
Architektura i japoński kolonializm - filmowy obraz przestrzeni miejskiej w okupowanym Seulu
}

\author{
Slowa kluczowe: \\ kino koreańskie; \\ kolonializm \\ japoński; \\ architektura; \\ przestrzeń miejska
}

\begin{abstract}
Abstrakt
Wychodząc z założenia, że związki architektury i kina powinny być rozpatrywane nie tylko w wymiarze estetycznym, lecz także w szerszym kontekście politycznym, Loska analizuje sposób, w jaki wielkomiejska sceneria współuczestniczy w kreowaniu narodowej mitologii oraz nostalgicznych wyobrażeń. Przedmiotem badań są dla autora współczesne filmy koreańskie rozgrywające się w okresie kolonizacji japońskiej (do 1945 r.), m.in. Utracona pamięć (reż. Lee Si-myung, 2002), Modern Boy (reż. Jung Ji-woo, 2008) i Pryæaatny detektyw (reż. Park Dae-min, 2009). Loska zwraca uwagę na fakt, że moda na kino retro wpisuje się w rewizjonistyczną strategię historyczną i jest próbą przepisania na nowo przeszłości. Odtwarzanie śladów obecności japońskich okupantów - przez cyfrowe rekonstrukcje przedwojennego Seulu - nie prowadzi do krytycznego namysłu nad kolonializmem, lecz służy wytwarzaniu określonej narracji, zgodnie z którą bohaterami filmów są członkowie ruchu oporu.
\end{abstract}


Powinowactwo architektury i sztuki filmowej od dawna wydawało się czymś intrygującym, zwłaszcza teoretykom z kręgu szkoły frankfurckiej. Jak zauważył przed laty Siegfried Kracauer, ulica wielkiego miasta w obiektywie kamery stanowi niewyczerpane źródło inspiracji dla nowoczesnego artysty ${ }^{1}$. Podobne zdanie wyraził niegdyś Walter Benjamin, który pisał o nieograniczonych możliwościach kamery zdolnej uchwycić wiele zjawisk otaczającego nas świata, poszerzyć przestrzeń i unaocznić ruch². Więź łączącą architekturę z filmem potwierdzały zarówno dzieła reżyserów związanych z awangardą okresu międzywojennego (m.in. Dziga Wiertow, René Clair, Walter Ruttmann), jak i oryginalnie zaprojektowane sale kinowe, które na stałe wpisały się w wielkomiejski krajobraz.

Kinematograf okazał się narzędziem pozwalającym opowiadać o miejscach bliskich i dalekich, zobrazować dynamikę życia społecznego, oddać jego emocje, wyrazić taktylny i optyczny sposób percepcji budynków, by się posłużyć określeniem Waltera Benjamina ${ }^{3}$. Związków architektury i filmu nie zamierzam rozpatrywać wyłącznie w wymiarze estetycznym, lecz pragnę dostrzec zawarty w nich potencjał polityczny, udział w kształtowaniu tożsamości i pamięci zbiorowej, a przy tym zdolność do wydobywania ukrytych prawd społecz$n y c h^{4}$. Na te właśnie aspekty chciałbym zwrócić szczególną uwagę, pisząc o współczesnych filmach koreańskich rozgrywających się w okresie kolonizacji japońskiej (do 1945 r.).

W analizowanych przeze mnie utworach architektura służy odzwierciedleniu pewnej wizji politycznej, uczestniczy w kreowaniu mitologii narodowej oraz przywoływaniu wspomnień, a raczej podkreślaniu ich nostalgicznego charakteru. Filmy koreańskie przekonują również o tym, że pamięć jest osadzona w konkretnych miejscach, może być wyobrażona $i$ zmaterializowana w przestrzeni miasta ${ }^{5}$. To budynki określają tożsamość każdej metropolii, tworzą jej wizerunek oraz współuczestniczą w konstruowaniu historii. Przeszłość żyje nie tylko w nas, ale i na zewnątrz, w przestrzeni publicznej - na ulicach, w kawiarniach, hotelach, domach towarowych - i to właśnie sprawia, że architektura jest sztuką pamięci, jak uważa Giuliana Bruno ${ }^{6}$.

Zamierzam wykazać, że koreańska moda na (post)kolonialne kino retro wpisuje się w rewizjonistyczną strategię polityczną i jest próbą przepisania na nowo przeszłości ${ }^{7}$. Przywracanie śladów obecności japońskich osadników oraz ukazanie ich wpływu na życie codzienne mieszkańców Korei nie zawsze prowadzi do krytycznego namysłu nad historia, ponieważ w kinie popularnym przeważa raczej zjawisko nostalgii, wyrażającej się w tęsknocie za utraconym czasem, w próbach odzyskania przeszłości czy raczej pewnego wyobrażenia o niej, odzwierciedlającego współczesne zapotrzebowanie na nowe mity narodowe i założycielskie. Takie podejście wyrosło z pokrzepiającej odmiany nostalgii, w której nacisk jest położony na nostos, czyli powrót do domu ${ }^{8}$.

Fascynacja przeszłością łączy się w dodatku ze skłonnością do promowania alternatywnej wersji historii lub chęcią przekształcenia jej zgodnie z dominującą narracją w której pierwszoplanową rolę odgrywają bohaterowie ruchu oporu gotowi poświęcić życie dla ojczyzny. Przekonują o tym liczne filmy koreańskie wyprodukowane po 2000 r.: Anarchiści (Anakiseuteu, reż. Yoo Young-sik, 2000), Utracona pamięć (2009 - Loseutu memrlijeu, reż. Lee Si-myung, 2002), Thomas An Jung-geun (Doma An Jung-geun, reż. Seo Se-won, 2004), Modern Boy (Modeon boi, reż. Jung Ji-woo, 2008), Prywatny detektyw (Geurimja sarin, reż. Park Dae-min, 2009), Zabójstwo (Amsal, reż. Choi Dong-hoon, 2015), Ostatnia księżniczka (Deokhye-ongju, reż. Hur Jin-ho, 2016), Gra cieni (Miljeong, reż. Kim Jee-woon, 2016).

Nie sposób jednak zrozumieć wspomnianych dzieł bez znajomości kontekstu historycznego i politycznego. Na początku ubiegłego wieku, tuż po zwycięskiej wojnie z Rosja, wojska japońskie rozpoczęły stopniowe przejmowanie kontroli nad Półwyspem Koreańskim. 25 lipca 1905 r. wszystkie tereny objęto protektoratem, a pięć lat później kraj utracił 
niepodległość, stając się kolejną - po Okinawie i Tajwanie - kolonią Imperium Wschodzącego Słońca. Koreańskie zasoby - naturalne i ludzkie - stużyć miały rozwojowi Cesarstwa, sama zaś Korea stanowić postuszne zaplecze dla planów japońskiej ekspansji ku Azji-poczatkowo gospodarczej, wkrótce potem także politycznej ${ }^{9}$. Kolonizację tłumaczono misją cywilizacyjna, przekonując podbitą ludność, że podstawowym celem jest wprowadzanie koniecznych reform, uprzemysłowienie oraz urbanizacja, pomijano jednak fakt, że procesy te miały zachodzić w wariancie narzuconym przez zwycięskie mocarstwo, co oznaczało, że rozwój w dużej mierze prowadził do zależności ekonomicznej. Skutkiem ubocznym japońskiej okupacji było jednak przyspieszenie procesu dojrzewania koreańskiego społeczeństwa do odzyskania świadomości narodowej, poczucia przynależności do jednej, odmiennej nacji, mającej prawo do samostanowienia ${ }^{10}$.

Przyjęty przez urzędników państwowych model zarządzania kolonią tylko we wczesnym okresie miał charakter militarny (tzw. rządy miecza, jap. mudan seiji), dość szybko okazało się bowiem, że znacznie bardziej efektywny sposób panowania zapewni hegemonia kulturowa, czyli zmuszenie grupy podporządkowanej do przyjęcia i uwewnętrznienia pożądanego systemu wartości bez stosowania siły. Jak pisał Leszek Kołakowski, hegemonia to panowanie środkami czysto kulturalnymi nad życiem duchowym całego społeczeństwa ${ }^{11}$. Japończycy zrozumieli także to, że jednym ze sposobów na utrwalenie władzy na Półwyspie jest zachowanie kontroli nad przestrzenią przez przejmowanie na własność ziemi oraz całościową przebudowę miast, które stałyby się symbolem nowego porządku w Azji Wschodniej. Na główny obiekt eksperymentu urbanizacyjnego wybrano Seul - czy też raczej Keijō (kor. Gyeongseong), jak nazywano wówczas stolicę Korei - ale plan rozbudowy objął w sumie trzynaście mias $\mathrm{t}^{12}$. Ważnym elementem składowym $\mathrm{w}$ tym projekcie modernizacyjnym było zbudowanie połączeń kolejowych między poszczególnymi prowincjami, co pozwoliłoby nie tylko na sprawne zarządzanie i rozwój osadnictwa, ale przede wszystkim na ekspansję terytorialną w kierunku Mandżurii jako potencjalnego celu dalszych podbojów kolonialnych.

Wzorem dla urbanistów japońskich pracujących w stolicy Korei był pełen rozmachu projekt przebudowy Paryża przygotowany przez barona Georges'a-Eugène'a Haussmanna (1809-1891), który w drugiej połowie XIX w. wyburzył część budynków w centralnych dzielnicach i zastąpił je szerokimi bulwarami, alejami, placami gwiaździstymi, parkami (m.in. Lasek Buloński) oraz setkami nowych budowli. Chcąc osiągnąć podobne efekty, urzędnicy kolonialni przyjęli pierwszy plan zagospodarowania przestrzennego dla wszystkich terenów miejskich. Zakładał on wybudowanie kilkudziesięciu nowych dróg oraz dostosowanie istniejących do geometrycznego układu mającego usprawnić komunikację i transport publiczny ${ }^{13}$.

W latach 20. ubiegłego wieku na łamach jedynego wydawanego w Korei czasopisma architektonicznego "Chōsen to kenchiku” zaczęły się ukazywać artykuły inspirowane utopijnymi ideami Miast Ogrodów Ebenezera Howarda (1850-1928) oraz modernistycznymi wizjami Le Corbusiera (1887-1965), jednak za wdrażanie teorii w życie odpowiadał Honma Takayoshi, dyrektor nowo utworzonego urzędu planowania przestrzennego, który zajmował się rewitalizacją starych dzielnic miasta. W szybkim tempie z pejzażu stolicy znikała dawna zabudowa koreańska zastępowana obiektami w stylu zachodnim oraz rezydencjami przeznaczonymi dla osadników japońskich. Jednak w ubogich dzielnicach, zamieszkanych głównie przez ludność rdzenna, wciąż dominowały tradycyjne domy drewniane (hanok) i ten właśnie kontrast udało się wydobyć w filmach nostalgicznych, zwłaszcza w Modern Boy i Grze cieni, w których bohaterowie poznają mroczną stronę projektu nowoczesności oraz zostają wciągnięci w półświatek przestępczy.

Przestrzeń publiczna szybko została zawłaszczona przez kolonizatorów, a nowe budowle miały potwierdzić postępujący proces asymilacji, która sprowadzała się do na- 
rzucenia określonego systemu wartości ${ }^{14}$. Modernizm jako projekt przebudowy świadomości stał się dla mieszkańców okupowanego kraju przede wszystkim „doświadczeniem szoku" (Schockerlebnis) - by użyć określenia Waltera Benjamina ${ }^{15}$ - ponieważ ich dotychczasowe życie rozpadło się na kawałki, nowe zaś miało zostać ukształtowane zgodnie z japońskimi wzorcami. Pejzaż stolicy szybko zdominowały monumentalne gmachy wznoszone w nowoczesnej technologii żelbetonowej, utrzymane w eklektycznej stylistyce inspirowanej zachodnimi wzorcami (neoklasycyzm, neobarok) ${ }^{16}$. Warto dodać, że projekt kolonialny zakładał nie tylko przekształcenie przestrzeni miejskiej przez Japończyków, ale również włączenie Koreańczyków w proces przemian, czemu miała służyć otwarta w 1916 r. szkoła inżynieryjna kształcąca przyszłych architektów. Nowa przestrzeń miejska oznaczała obecność strefy kontaktu i wymiany międzykulturowej, która nie sprowadzała się wyłącznie do jednokierunkowej relacji między dominującymi i podporządkowanymi, chociaż filmowa przyjaźń koreańsko-japońska zazwyczaj przeradzała się w rywalizację lub otwarty konflikt (Utracona pamięć, Modern Boy).

Moim celem nie jest jednak omówienie historii architektury w kolonialnym Seulu, ale wskazanie na jej funkcję $w$ filmach koreańskich rozgrywających się $w$ tamtych czasach. Kino nostalgiczne opiera się bowiem na wytworzeniu wrażenia autentyczności na poziomie wizualnym za pomocą kostiumów z epoki oraz scenerii przedstawiającej szybko modernizujące się miasto, w którym ścierają się różnorodne wpływy. Z jednej strony twórcy wskazują na obecność okupantów za pomocą ujęć przedstawiających budynki publiczne (np. dworce kolejowe) oraz urzędy japońskie, ale z drugiej strony podkreślają pewną niezależność, czyli wszystko to, co się wiąże z mobilnością (samochody, ulice) i kulturą konsumpcyjną (sklepy, nocne kluby, kawiarnie, teatry).

Ważną rolę we wspomnianych filmach odgrywa rekonstrukcja architektury kolonialnej, która częściowo została zniszczona lub przebudowana po wojnie, co dotyczy zwłaszcza siedziby gubernatora generalnego (Joseon Chongdokbu Choengsa), czyli symbolu japońskiej okupacji na Półwyspie Koreańskim. Wielokondygnacyjny gmach rządowy, który pojawił się w m.in. w Utraconej pamięci, Modern Boy i Grze cieni, został zaprojektowany w stylu neoklasycznym przez Georga de Lalande (1872-1914), absolwenta politechniki berlińskiej, ukończony zaś w 1926 r. przez japońskiego inżyniera Nomurę Ichirō (1868-1942). Ze względu na położenie wywołał liczne kontrowersje, ponieważ Japończycy przejęli część terenów, na których stał pałac królewski (Gyeongbok). Koreańczycy uznali taką decyzję za przejaw "duchowej kolonizacji”, ingerencję w żywą tkankę narodu oraz próbę unieważnienia dziedzictwa historycznego. Z tego powodu w patriotyczno-narodowej narracji, która dominuje we współczesnych filmach retro, wielokrotnie powraca wątek dotyczący wysadzenia w powietrze fikcyjnej lub rzeczywistej siedziby władz okupacyjnych. Przygotowywane przez bohaterów Anarchistów czy Gry cieni zamachy i akty sabotażu miały stanowić przykład strategii oporu, czyli odpowiedź na przemoc kolonialną.

Projekt urzędu gubernatora generalnego Korei powstał niedługo po formalnej aneksji kraju. Władze okupacyjne chciały, by stał się wzorcowym przykładem nowoczesnej architektury zrywającej z dotychczasowym porządkiem i lokalną tradycją której ucieleśnieniem był pałac dynastii Joseon (wzniesiony pod koniec XIV w., lecz częściowo zniszczony podczas wojny koreańsko-japońskiej w latach 1592-1598). Chodziło o wyraźne podkreślenie faktu zastąpienia starej władzy przez nową i dlatego horyzontalny układ przestrzenny - wyróżniający pozostałości po dawnym pałacu królewskim - zastąpiono konstrukcją wertykalną. Nad symetryczną, czteropiętrową budowlą wykonaną z żelbetonu oraz szarego granitu wznosiła się wysoka wieża zwieńczona miedzianą kopułą, co potwierdzałoby tezę Thomasa R. Metcalfa, że architektura jest jednym z przejawów związu łączacego 
wiedzę i władzę, który stanowił podstawę kolonializmu ${ }^{17}$. Okupacyjna trauma, z którą zmagały się kolejne pokolenia Koreańczyków, ogniskowała się właśnie wokół siedziby gubernatora, zwłaszcza że po odzyskaniu niepodległości w $1945 \mathrm{r}$. pełnił on nadal funkcję polityczna, goszcząc przedstawicieli zgromadzenia narodowego.

Wielu badaczy zwraca uwagę na związek łączący proces modernizacji zachodzący w koloniach z kształtowaniem nowej przestrzeni miejskiej, będącej nie tylko efektem urbanizacji i industrializacji, ale też odzwierciedleniem polityki osadnictwa. Kolonizatorzy, za pośrednictwem monumentalnych gmachów typowych dla zachodnioeuropejskiej tradycji klasycznej, wyrażali swoje poparcie dla idei nowoczesnej cywilizacji ${ }^{18}$. Z kolei w epoce postkolonialnej wyburzanie dawnych budynków stanowiło element $\mathrm{w}$ wojnie o pamięć, polegającej na wytworzeniu odmiennej narracji historycznej, wyrosłej na gruncie nowego nacjonalizmu. W 1993 r., po przejęciu władzy przez prezydenta Kim Young-sama, rozpoczął się proces naprawiania historii koreańskiej, widoczny w krytyce dziedzictwa kolonialnego oraz przywracaniu ducha narodowego ${ }^{19}$. Pierwszoplanową rolę odgrywał projekt rozbiórki dawnego gmachu gubernatora, którą rozpoczęto w czterdziestą rocznicę odzyskania niepodległości (15 sierpnia 1995 r.), oraz rekonstrukcji pałacu królewskiego jako symbolu ciągłości tradycji koreańskiej.

Jak słusznie zauważyła Eleni Bastéa, architektura potrafi uchwycić ulotne lub natarczywe wspomnienia i nadać im namacalny kształt, jest więc poniekąd teatrem pamięci $i^{20}$. Pozostaje jedynie pytanie, kto kształtuje wspomnienia i do kogo one należą, jako że podejmowane w minionym ćwierćwieczu decyzje rządu koreańskiego pokazują w jaki sposób manipuluje się pamięcią. Wymazywanie z przestrzeni określonych budynków, placów, pomników oraz rekonstruowanie śladów dawnej wielkości jest działaniem na wskroś politycznym i pełni funkcję symboliczną. Pod koniec ubiegłego stulecia wydawało się, że odzyskiwanie przeszłości polega w dużej mierze na ustanawianiu nowych miejsc pamięci oraz wymazywaniu pozostałości po okupacji japońskiej. Strategia ta potwierdzała niechęć władzy do pamiętania o traumatycznej historii, a zarazem zapowiadała stworzenie nowej mitologii antykolonialnego oporu, która odegrała ważną rolę we wspomnianych wcześniej filmach koreańskich.

Spóźniona dekolonizacja oznaczała nie tylko upamiętnienie bohaterskich czynów, ale również konieczność rozliczenia tych, którzy kolaborowali z okupantami, stąd powołanie specjalnych komisji śledczych, publikowanie materiałów historycznych oraz domaganie się zadośćuczynienia - także finansowego - od rządu japońskiego. Motyw współpracy z Japończykami powraca jako wątek poboczny w Utraconej pamięci, Zabójstwie, Modern Boy, Grze cieni oraz jako główny temat w Błękitnej jaskółce (Cheong-yeon, reż. Yun Jong-chan, 2005 ${ }^{21}$. Bruce Cumings stwierdził, że dla historyków koreańskich okres kolonialny jest zarówno zbyt bolesny, jak i nazbyt określony przez mitologię oporu, która nie znajduje potwierdzenia w żadnych materiałach archiwalnych ${ }^{22}$. Do pewnego stopnia odpowiedzią na ten brak danych historycznych są dzieła filmowe, które podtrzymują fantazmatyczne wyobrażenie na temat antykolonialnej działalności bojowników o niepodległość.

Nowe filmy koreańskie, których akcja rozgrywa się w okresie okupacji japońskiej, potwierdzają że zapomnienie o tamtych czasach jest niemożliwe, że widma przeszłości nawiedzają teraźniejszość, a obecne pokolenie próbuje odzyskać to, co zostało utracone ${ }^{23}$. Ślady pamięci są odciśnięte nie tylko w czasie, ale również w przestrzeni i dlatego powstają projekty zrekonstruowania przebudowanego przez Japończyków miasta. Marzeniom o odzyskaniu historycznego Seulu towarzyszy nierzadko ignorowanie autentycznej historii, traktowanej selektywnie. Wydaje się, że reżyserzy koreańscy, podobnie jak politycy, wybierają te elementy, które pasują do narodowej układanki, co do pewnego stopnia świadczy o historycznej amnezji. Jak zauważyła Cynthia Childs, filmy rozgrywające się w tamtych 
czasach mówią więcej na temat sposobów konstruowania tożsamości narodowej oraz współczesnej sytuacji politycznej w Korei niż o traumatycznej przeszłości ${ }^{24}$.

Ocena procesu modernizacji, przebiegającego w Korei pod dyktando Japończyków, jest niejednoznaczna, co potwierdzają publikacje z ostatniego dwudziestolecia, których autorzy zwracali uwagę nie tylko na system opresji kolonialnej, ale także na życie codzienne mieszkańców oraz rozwój kultury masowej ${ }^{25}$. Za jeden ze składników nowoczesnego pejzażu miejskiego uznano sale kinowe. To one, obok domów towarowych i kawiarni, stały się centralnymi punktami dzielnic rozrywki, po których przechadzały się "nowoczesne dziewczyny" - modeon geol (jap. modan gāru) - oraz towarzyszący im młodzi mężczyźni ${ }^{26}$.

Doskonałą ilustracją powyższego zjawiska jest film Modern Boy, który rozpoczyna się od serii czarno-białych ujęć pochodzących z japońskich dokumentów nakręconych w latach 20. i 30. Dzięki temu prologowi widzowie mogli zobaczyć miejsca znane z okupowanego Seulu - czy raczej Gyeongseong, ponieważ takiej nazwy używano - nowoczesny dworzec kolejowy wybudowany w 1925 r., pięciopiętrowy dom towarowy Mitsukoshi otwarty w 1930 r., XX-wieczną katedrę Najświętszej Marii Panny w dzielnicy Myeongdong oraz siedzibę gubernatora generalnego. Sekwencja inicjalna pokazuje, że architektura i urbanistyka są narzędziami sprawowania władzy i kształtowania tożsamości zbiorowej.

W znacznym stopniu obrazy te prezentują modernizujące się miasto, z jego szerokimi ulicami, migającymi światłami neonów, ruchem samochodowym i tramwajowym, ale na drugim planie widać również kryte strzechą tradycyjne domy koreańskie czy pochodzącą z XIV w. bramę Sungnyemun w kształcie pagody - jeden z najstarszych i najcenniejszych zabytków architektury koreańskiej (częściowo zniszczony wskutek podpalenia w 2008 r.). Jo Sang-gyeong, autorka scenografii, wspominała w jednym z wywiadów, że chcąc stworzyć wrażenie autentyczności, swoje projekty wzorowała na wizerunku miasta, jaki został utrwalony w najstarszym zachowanym filmie koreańskim, czyli Młodzieży na rozstajach dróg (Cheongchun uisibjalo, reż. Ahn Jong-hwa, 1934) ${ }^{27}$.

Archiwalne fotografie z lat 30. ukazują Seul jako miasto atrakcyjne, pełne życia, szybko rozwijające się (liczyło ponad milion mieszkańców). Sekwencja inicjalna kończy się napisami tytułowymi, po których pojawia się kolor i cyfrowo zrekonstruowane miasto, które można było wcześniej zobaczyć na czarno-białych zdjęciach - jak gdyby fantazmatyczna przeszłość nakładała się na jej realne obrazy. Posłużenie się efektami komputerowymi pozwoliło na wykreowanie fantazji, w której rzeczywistość zmienia się w mit (czy może raczej w simulacrum). Warto jednak zwrócić uwagę, że przywoływanie utraconego czasu dokonuje się w filmie Junga dzięki wykorzystaniu materiałów nakręconych w celach propagandowych, przypominających o tym, że modernizacja stanowiła część składową projektu kolonialnego.

Twórcy filmu nieprzypadkowo wybrali wymienione powyżej budynki, wszystkie one pełnią bowiem określoną funkcję narracyjną. Na ich tle rozgrywa się historia Hae-myeonga (Park Hae-il), absolwenta tokijskiego uniwersytetu, pracownika kolonialnej administracji, prowadzącego luksusowe życie przedstawiciela warstwy uprzywilejowanej, który zakochuje się w niewłaściwej kobiecie. Charakterystyczne dla nostalgicznych produkcji w stylu retro jest wykorzystywanie popularnych schematów gatunkowych, począwszy od melodramatu, przez musical, po thriller szpiegowski. Główny bohater poznaje piękną i zmysłową Laurę (Kim Hye-su) - czy może raczej Nan-sil lub Nataszę, gdyż tymi imionami się posługuje - typową femme fatale, która wciąga go w sieć szpiegowskich intryg. Tajemnicza kobieta jest nie tylko piosenkarką i tancerką, ale przede wszystkim członkinią ruchu oporu, która ma do wypełnienia niebezpieczną misję. To dzięki niej mężczyzna przechodzi 
przemianę w bojownika o wolność, który dla dobra sprawy poświęca karierę zawodową oraz szczęście osobiste.

Tytuł filmu nawiązuje do zjawiska "nowoczesnych chłopców i dziewcząt” (modeon geol, modeon boi), o które spierano się w koreańskiej prasie kolonialnej ${ }^{28}$. Dziennikarze i intelektualiści krytycznie oceniali nadmierne przywiązanie do kultury konsumpcyjnej, uleganie zachodniej modzie oraz naśladowanie amerykańskiego stylu życia. Wszystkie negatywne cechy reprezentuje Hae-myeong, który każdy dzień rozpoczyna od filiżanki kawy, słucha muzyki jazzowej, nosi biały garnitur i do klubów tanecznych jeździ czerwonym sportowym samochodem. W dodatku jest wzorcowym przykładem japońskiego programu asymilacyjnego (dōka): doskonale mówi w języku okupantów, pracuje jako architekt $\mathrm{w}$ urzędzie gubernatora generalnego i przyjaźni się z przybyłym z Tokio prokuratorem, co czyni z niego typowego kolaboranta ${ }^{29}$.

Podobnie jak w pozostałych filmach opisujących kolonialną przeszłość, także w tym pojawia się ambiwalentna ocena wielkomiejskiego życia, ponieważ światła latarni ulicznych i neonów reklamowych są skontrastowane z mrocznymi zaułkami i podejrzanymi spelunkami. Kiedy bohater postanawia odnaleźć uwodzicielską piękność, stopniowo odkrywa inne oblicze miasta, które nie jest już atrakcyjną metropolią, lecz siedliskiem rozpusty i chaosu. Kolejne sceny przypominają widzom, że bogate i eleganckie budynki sąsiadowały wówczas z ulicami nędzy, po których chodzili żebracy i sprzedawcy. W ten sposób rozpoczyna się dla Hae-myeonga poznawanie ukrytej prawdy o otaczającym świecie - mogłaby to być podróż do jądra ciemności, gdyby nie snopodobna atmosfera i nostalgiczny nastrój, które dominują w filmie Junga Ji-woo.

Zaniedbane dzielnice wielkiego miasta oraz ciemne zaułki, w których popełniane są zbrodnie, stały się scenerią innego filmu przywołującego atmosferę pierwszej połowy XX w. W warstwie fabularnej i wizualnej reżyser Prywatnego detektywa, Park Dae-min, nawiązuje do czarnej odmiany kryminału, o czym świadczą: sposób prowadzenia narracji, wykorzystanie światłocienia, nietypowe ustawienia kamery czy użycie głębi ostrości. W świecie przedstawionym panuje wszechobecna atmosfera zepsucia i rozkładu, którego symbolem jest wielki namiot cyrkowy należący do kolaboranta handlującego ludźmi. Śledztwo prowadzone przez prywatnego detektywa, Jin-ho (Hwang Jung-min), i studenta medycyny, Gwang-su (Ryu Deok-hwan), prowadzi do zdemaskowania grupy przestępczej, w której działają urzędnicy kolonialni oraz ich koreańscy poplecznicy ${ }^{30}$. Z poetyki filmu czarnego korzysta również reżyser Gry cieni, który dwie metropolie - Szanghaj i Seul - filmuje noca, w strugach deszczu, lecz mroczną scenerię kontrastuje z obrazami konsumpcyjnego raju, jakim był wówczas dom towarowy Mitsukoshi, zaś pełne napięcia sekwencje akcji umieszcza na dworcu kolejowym - symbolu koreańskiej architektury modernistycznej, zaprojektowanym przez Japończyka Tsukamoto Yasushiego ${ }^{31}$.

Strategią narracyjną stosowaną z upodobaniem przez reżyserów koreańskich jest przypominanie widzowi o tym, że ogląda minione wydarzenia z dzisiejszej perspektywy: przez obecność retrospekcji, zastosowanie ramy czasowej lub wprowadzenie wstawek z teraźniejszości; czasem tę odmienność akcentuje się wizualnie za pomocą przejścia od sekwencji nakręconych na taśmie czarno-białej do scen $\mathrm{w}$ kolorze ${ }^{32}$. Wszystkie te elementy służą podkreśleniu nieciągłości wynikającej z natury pamięci naznaczonej traumatycznymi przeżyciami, co sprawia, że minione wydarzenia wciąż wywierają wpływ na teraźniejszość. Wpisujące się $\mathrm{w}$ nacjonalistyczną politykę historyczną filmy nostalgiczne nie pozwalają jednak na krytyczne zmierzenie się z przeszłościa, próbują raczej zaklinać ja, a ich twórcy wychodzą z założenia, że trzeba w magiczny sposób przepędzić widmo, wyegzorcyzmować możliwy powrót mocy, która uznaje się za złowroga, oddalić płynace z jej strony demoniczne zagrożenie ${ }^{33}$. 

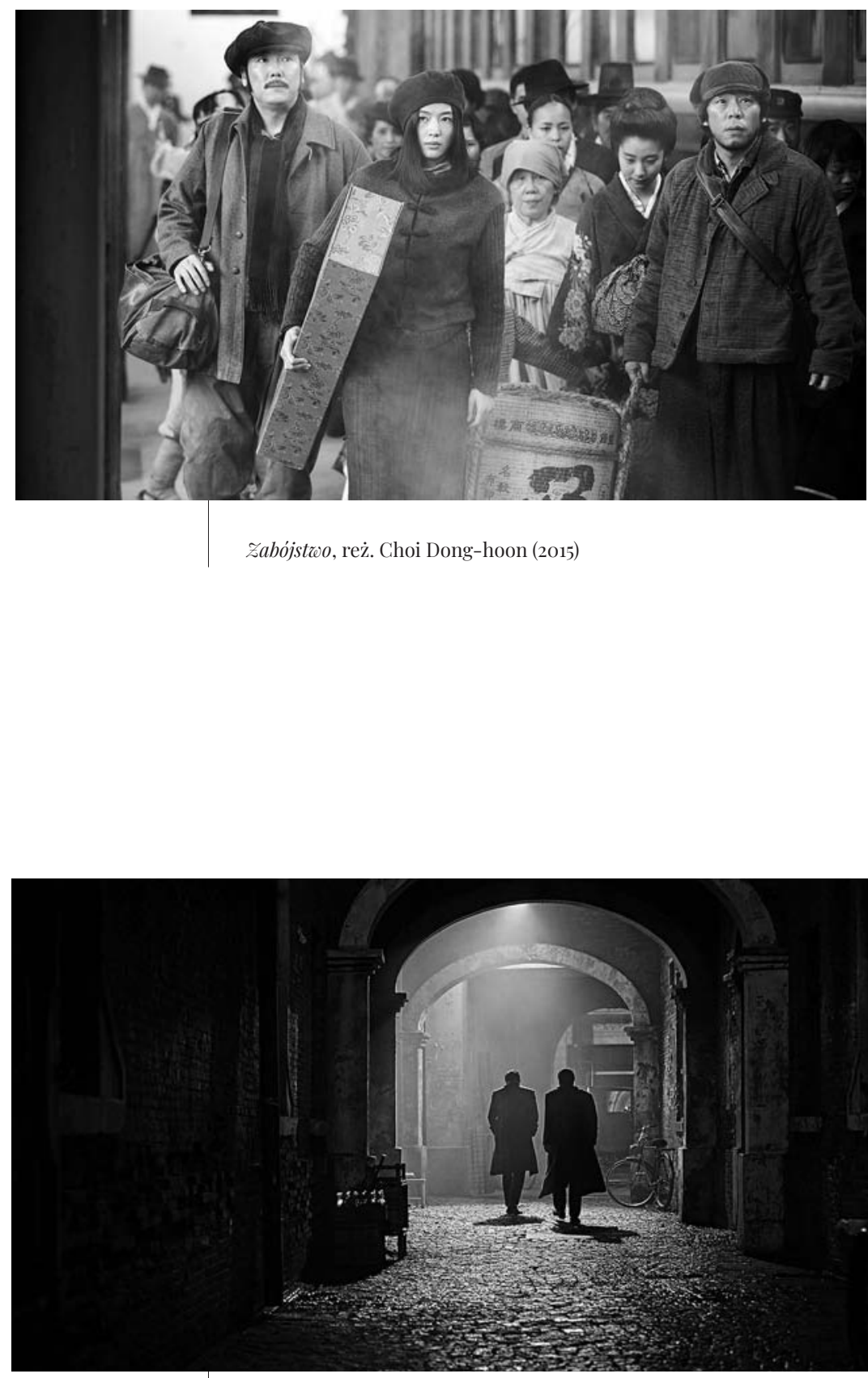

Gra cieni, reż. Kim Jee-woon (2016) 
Czasem motyw nawiedzania przez widma z przeszłości jest potraktowany dosłownie, jak chociażby w horrorze Epitafium (Gidam, reż. Jung Sik i Jung Bum-shik, 2007), którego akcja rozgrywa się na dwóch płaszczyznach czasowych: w lutym 1942 r. i 35 lat później. Bohaterem jest profesor Park Jung-nam (Jeon Mu-song), który pewnego dnia znajduje album ze zdjęciami pochodzącymi z czasów, kiedy jako młody lekarz pracował w szpitalu, gdzie doszło do serii tajemniczych morderstw. Pochodzący z czasów kolonialnych budynek szpitalny jest nie tylko scenerią typową dla filmów grozy, ale przede wszystkim symbolem okupacji japońskiej, jako że początek 1942 r. to okres wielkich zwycięstw armii cesarskiej w Azji Południowo-Wschodniej. Nie mniej istotna jest inna data, 26 października 1979 r., czyli dzień śmierci bohatera filmu, a jednocześnie zamachu na prezydenta Korei Parka Chung-hee (w czasie okupacji studiował on w japońskiej szkole oficerskiej i posługiwał się nazwiskiem Takagi Masao) $)^{34}$.

Przenikanie się różnych porządków czasowych nie jest niczym niezwykłym w koreańskich filmach nostalgicznych, o czym przekonuje Utracona pamięć, jeden z pierwszych obrazów zapowiadających modę na kino (post)kolonialne, którego funkcją jest nie tyle krytyczne spojrzenie na przeszłość, ile raczej spopularyzowanie narracji narodowej, będącej odpowiedzią na zapotrzebowanie polityczne. Historia w filmie Lee Si-myunga nie jest czymś obiektywnym, ale wytwarzanym w procesie konstruowania narracji, jest nośnikiem wartości i pamięci kulturowej, co sprawia, że rywalizujące ze sobą narody - koreański i japoński - walczą o przejęcie kontroli nad czasem minionym czy może raczej wyobrażeń na jego temat.

Punktem rozszczepienia - czyli wydarzeniem, które doprowadziło do wytworzenia całkowicie odmiennej wersji historii - jest w Utraconej pamięci autentyczna opowieść o zabójstwie Itō Hirobumiego (1841-1909), generalnego rezydenta (sokan) Korei i byłego premiera Japonii. Za logistykę i wykonanie operacji odpowiadał głównie An Jung-geun (1879-1910), członek koreańskiego ruchu oporu. Sekwencja inicjalna rozgrywa się na dworcu w Harbinie w dniu zamachu, jednak bohater nie wypełnia misji, ponieważ ginie zastrzelony przez jednego z funkcjonariuszy japońskiej policji (wysłannika z przyszłości). Właściwa akcja rozpoczyna się sto lat później w Seulu od ataku terrorystycznego przeprowadzonego przez bojowników z organizacji Fureisenjin, odłamu Koreańskiej Armii Wyzwoleńczej ${ }^{35}$. Okazuje się, że w 2009 r. Korea nie istnieje jako niepodległe państwo, lecz jest częścią wielkiego imperium japońskiego i tylko nieliczni patrioci walczą z okupantami.

Zgodnie ze schematem opowieści fantastycznonaukowych rozgrywających się w alternatywnej rzeczywistości, bohater - Koreańczyk Sakamoto Masayuki (Jang Dong-gun) dowiaduje się, że znana mu historia została zmieniona dzięki tajemniczemu artefaktowi, który pozwala na otwarcie wrót czasu i przeniesienie się do przeszłości. Członkowie ruchu oporu, do których w pewnym momencie przyłącza się Sakamoto, pragną odzyskać przedmiot i przenieść się w przeszłość, by naprawić „,zwichnięty” czas. Retroaktywne tworzenie tożsamości narodowej dokonuje się dzięki wykorzystaniu starożytnego obiektu, odkrytego przez archeologów prowadzących wykopaliska w okolicach Harbinu w 1923 r., który pozwala na otwarcie portalu czasoprzestrzennego. Tajemniczy przedmiot pochodzący z prehistorycznych czasów, wykorzystywany w obrzędach religijnych jako nóż ofiarniczy, nie tylko umożliwia podróże w czasie, ale - podobnie jak stela króla Gwanggaeto - jest dowodem minionej wielkości państwa koreańskiego ${ }^{36}$.

Film Lee Si-myunga można odczytywać jako świadectwo ścierania się różnych wersji przeszłości (kwestia dziedzictwa ruchu niepodległościowego), dowód upolitycznienia pamięci (kontrola nad dyskursem patriotycznym) i swoistej wojny na wspomnienia (la guerre des mémoires) - by się posłużyć określeniem Benjamina Story ${ }^{37}$ - o czym świadczą fi- 
nałowe sceny Utraconej pamięci rozgrywające się w 1909 r., w których niegdysiejsi partnerzy i przyjaciele, Japończyk i Koreańczyk, stoją po przeciwnych stronach barykady i muszą zdecydować o losie swoich krajów. Film kończy zbliżenie czarno-białej fotografii przedstawiającej bojowników o niepodległość (wśród nich jest Sakamoto), będącej świadectwem alternatywnej historii, która wymazała kolonializm oraz podziały ideologiczne wynikające z zimnej wojny ${ }^{38}$.

Odzyskanie dziedzictwa przeszłości okazuje się możliwe wyłącznie dzięki poświęcaniu nielicznych patriotów żyjących w alternatywnej teraźniejszości, która powstała wskutek zniekształcenia biegu historii. W ten sposób Utracona pamięć można odczytywać jako alegorię narodowa, czyli opowieść o walce o niepodległość, próbę podtrzymania mitu ruchu oporu jako niezbędnego składnika tożsamości zbiorowej, który pojawia w niemal wszystkich filmach rozgrywających w czasach kolonialnych. Historie alternatywne pełnią zazwyczaj funkcję dydaktyczną i pomimo fantazmatycznego charakteru są wprzęgnięte w bieżącą politykę historyczną. Z jednej strony chodzi o usunięcie bolesnych wspomnień upokorzenia i podporządkowania - zwłaszcza współpracy Koreańczyków z okupantami z drugiej o upamiętnianie bohaterów, zarówno tych prawdziwych (Kim Gu, An Jung-geun), jak i wymyślonych.

Ze względu na wymowę ideologiczną koreańskie filmy nostalgiczne osadzone w epoce kolonialnej można porównać do europejskiego kina dziedzictwa (fr. cinéma de patrimoine, ang. heritage cinema), które pod koniec ubiegłego stulecia służyło umacnianiu tożsamości zbiorowej oraz budowaniu poczucia przynależności do wspólnoty wyobrażonej ${ }^{39}$. Obrazy należące do tego nurtu proponują zazwyczaj interpretację historii zgodną z oficjalną wersją pamięci kulturowej. Od czasu do czasu zdarzają się jednak utwory, które podważają dominującą narrację narodową i mierzą się z niejednoznacznym dziedzictwem przeszłości. W kinie koreańskim dotyczy to zwłaszcza skutków polityki asymilacyjnej oraz dobrowolnej współpracy części społeczeństwa z władzami okupacyjnymi.

Przykładem, który w umiejętny sposób łączy narrację patriotyczną, podtrzymującą mit heroicznego wysiłku koreańskiego ruchu oporu, z postawą krytyczną, jest Zabójstwo Choi Dong-hoona. Podjęty przez reżysera temat kolaboracji i zdrady w podziemiu niepodległościowym wiąże się z pytaniem o nierozliczone zbrodnie z czasów kolonialnych oraz wskazuje potrzebę rozrachunku z historią. Nie zamierzam jednak skupiać się na wątkach politycznych, pragnę raczej zwrócić uwagę na sposób, w jaki kreowane są nostalgiczne wyobrażenia przeszłości. Twórcy nie ograniczyli się do cyfrowej rekonstrukcji Seulu, lecz sfilmowali zachowane budynki oraz zbudowali makiety po to, by odtworzyć klimat kolonialnej metropolii.

Wykorzystanie układu przestrzennego stolicy z jej charakterystycznymi punktami orientacyjnymi - dworcem kolejowym i domem towarowym Mitsukoshi - nie jest celem samym w sobie, lecz zostaje podporządkowane logice narracyjnej. Bohaterowie filmu znajdują się w ciągłym ruchu - przemieszczają się rikszami, tramwajami i samochodami - przemierzają boczne uliczki, odwiedzają bary, robią zakupy w ekskluzywnych sklepach i spotykają się w kawiarni prowadzonej przez członkinię ruchu oporu. Wszystko to pozwala uchwycić panoramę modernizującego się Seulu, w którym tradycja sąsiaduje z nowoczesnością. Przygotowania do zamachu na życie japońskiego generała Kawaguchiego (Shim Cheol-jong) i jego koreańskiego wspólnika, Kang In-guka (Lee Geung-young), są prowadzone z planem miasta w ręku. Powodzenie akcji jest uzależnione od wyboru właściwego miejsca na ostrzelanie konwoju jadącego na dworzec centralny ${ }^{40}$.

Omawiane przeze mnie filmy niewątpliwie stanowią część zjawiska, które nasiliło się na przełomie stuleci, związanego ze wzrostem zainteresowania historią kolonialną i spo- 
sobem postrzegania jej jako czegoś egzotycznego i atrakcyjnego. Potwierdzeniem zmieniającego się stosunku do traumatycznej przeszłości są publikowane albumy ze starymi fotografiami czy cieszące się wielką popularnością widokówki przedstawiające modne ulice, kawiarnie i sklepy z czasów kolonialny $\mathrm{ch}^{41}$. To właśnie na nich - podobnie jak w filmach można zobaczyć milionową metropolię rządzoną przez okupantów, pulsującą życiem i rozwijającą się w zawrotnym tempie, w której modernistyczne gmachy zaprojektowane w europejskim stylu stoją obok tradycyjnych domów (hanok). Obrazy te organizują wizualną pamięć miasta, są materialnymi śladami przeszłości, która nigdy nie stała się częścią oficjalnej historii narodu.

Koreańskie filmy nostalgiczne przekonuja, że wszystko, co wyparte, powraca w zmienionej - nierzadko fantazmatycznej - formie, że odzyskiwanie wspomnień jest $\mathrm{w}$ istocie produkowaniem ich na nowo, przy użyciu zaawansowanej technologii cyfrowej pozwalającej na wykreowanie wrażenia autentyczności. Z jednej strony dzieła te można uznać za przejaw szerszego procesu wytwarzania pamięci zbiorowej, jako że wskazują na wyraźną cezurę oddzielającą epokę kolonialną od postkolonialnej ${ }^{42}$, z drugiej zaś, sygnalizują istnienie pewnej luki, pęknięcia, które przejawia się w widmowej obecności budynków i ludzi, przypominając o tym, o czym pragnie się zapomnieć.

${ }^{1}$ Por. A. Vidler, Warped Space: Art, Architecture, and Anxiety in Modern Culture, The MIT Press, Cambridge 2000, s. 113.

${ }^{2}$ W. Benjamin, Dzieło sztuki w dobie reprodukcji technicznej, tłum. J. Sikorski, w: tegoż, Aniot historii, Wydawnictwo Poznańskie, Poznań 1996, s. 230.

${ }^{3}$ W polskim wydaniu Dzieła sztuki w dobie reprodukcji technicznej błędnie przetłumaczono kluczowe sformułowanie Benjamina - taktil und optisch - dotyczące podwójnego wymiaru percepcji budynków. Janusz Sikorski konsekwentnie posługuje się słowem "taktyczny” zamiast "taktylny" (tamże, s. 235).

${ }^{4}$ A. Holmes, Politics of Architecture in Contemporary Argentine Cinema, Palgrave Macmillan, London 2017, s. 1.

${ }^{5}$ B. Pabjan, P. Czajkowski, Pamieć zbiorowa a przestrzeń miasta, „Forum Socjologiczne” 2015, nr 6, s. 10.

${ }^{6}$ G. Bruno, Atlas of Emotion: Journeys in Art, Architecture, and Film, Verso, London - New York 2018, s. 8.

${ }^{7}$ Wieloaspektową analizę nostalgicznego wymiaru w kinie retro zaproponowała Patrycja Włodek w książce Kres niewinności. Obraz i upamiętnienie ery Eisenhowera w amerykańskich filmach $i$ serialach - pomiędzy reprezentacja, nostalgia a krytycznym retro, Wydawnictwo Uniwersytetu Pedagogicznego, Kraków 2018.

${ }^{8}$ S. Boym, The Future of Nostalgia, Basic Books, New York 2001, s. 18. Autorka przeciwstawia nostalgię pokrzepiająca, która wyrasta z pragnienia odzyskania tego, co utracone, nostalgii refleksyjnej, odwołującej się do tęsknoty i odwlekającej chwilę powrotu. O nostalgicznym aspekcie filmów poruszających problematykę kolonialną pisałem w artykule Czas utracony - nostalgia i trauma $w$ postkolonialnym filmie francuskim, „Kwartalnik Filmowy" 2014, nr 86, s. 92-103.

${ }^{9}$ J. Rurarz, Historia Korei, Wydawnictwo Akademickie Dialog, Warszawa 2009, s. 329.

${ }^{10}$ Tamże, s. 330.

${ }^{11}$ L. Kołakowski, Główne nurty marksizmu. Część III: Rozkład, Wydawnictwo Krąg, Warszawa 1989, s. 982. Pojęcie hegemonii wprowadził włoski historyk, filozof i polityk Antonio Gramsci (1891-1937).

${ }^{12}$ Por. I. Chŏng, Architecture and Urbanism in Modern Korea, University of Hawai'i Press, Honolulu 2013, s. 4.

${ }^{13}$ Japońscy architekci zaczęli przybywać do Seulu jeszcze przed formalną aneksją kraju, $\mathrm{z}$ nadzieją że znajdą $\mathrm{w}$ tym mieście doskonały poligon doświadczalny. Iwai Chōzaburō, Kunieda Hiroshi i Watanabe Setsu przystąpili do stawiania szpitali, szkół, urzędów miejskich, posterunków policji. Wkrótce dołączyli do nich Tatsuno Kingo, który zaprojektował siedzibę Banku Koreańskiego, oraz Nomura Ichirō, odpowiedzialny za ukończenie siedziby gubernatora generalnego.

${ }^{14}$ Sposób narzucania nowych wartości wiązał się ściśle ze zmianą układu architektonicznego, o czym świadczy nie tylko gmach gubernatora generalnego, ale również olbrzymi kompleks świątyń sintoistycz- 
nych wybudowanych na górze Namsan, najwyższym punkcie Seulu, który potwierdzał japońskie panowanie zarazem w wymiarze materialnym i duchowym.

${ }^{15}$ Pojęciem szoku w odniesieniu do doświadczenia modernizmu Walter Benjamin posługuje się zarówno we wczesnych tekstach, np. Ulica jednokierunkowa (tłum. B. Baran, Wydawnictwo Aletheia, Warszawa 2011), jak i późnych - O kilku motywach u Baudelaire'a, w: tegoż, Konstelacje. Wybór tekstów, tłum. A. Lipszyc, A. Wołkowicz, Wydawnictwo Uniwersytetu Jagiellońskiego, Kraków 2012.

${ }^{16}$ Niektórzy architekci japońscy podróżowali do Europy i Stanów Zjednoczonych, by tam zdobywać doświadczenie i szukać inspiracji dla własnych pomysłów. Kunieda Hiroshi pojechał do Waszyngtonu, by przyjrzeć się tamtejszym budynkom rządowym i przystosować je do oczekiwań japońskich zleceniodawców. Por. Y. Nishizawa, A Study of Japanese Colonial Architecture in East Asia, w: Constructing the Colonized Land: Entwined Perspectives of East Asia around WWII, red. I. Kuroishi, Routledge, London 2016, s. 11-30 .

17 T. R. Metcalf, An Imperial Vision: Indian Architecture and Britain's Raj, University of California Press, Berkeley 1989, s. 8.

${ }^{18}$ C. Hsia, Theorizing Colonial Architecture and Urbanism: Building Bolonial Modernity in Taiwan, „Inter-Asia Cultural Studies” 2002, t. 3, nr 1, s. 10.

${ }^{19}$ Por. S. Kim, Re-locating the National: Spatialization of the National Past in Seoul, „Policy Futures in Education" 2009, t. 7, nr 2, 256-265.

${ }^{20}$ E. Bastéa, Introduction, w: Memory and Architecture, red. E. Bastéa, University of New Mexico Press, Albuquerque 2004, s. 1. Określeniem architektury jako "teatru pamięci" posłużył się Umberto Eco w artykule Architecture and Memory, "VIA" 1986, t. 8, s. 94.

${ }^{21}$ Pomimo istotnego znaczenia $\mathrm{w}$ debacie na temat kolonializmu Błękitna jaskółkę pomijam w niniejszych rozważaniach, ponieważ scenerią wydarzeń nie jest Seul. Interesującą analizę Gry cieni, Zabójstwa i Modern Boy proponuje Kevin Michael Smith, Vicarious Politics: Violence and the Colonial Period in Contemporary South Korean Film, "The Asia-Pacific Journal" 2017, t. 15, nr 3.

${ }^{22}$ B. Cumings, Korea's Place in the Sun: A Modern History, Norton, New York - London 2005, s. 139.

${ }^{23}$ Catherine Russell widzi w filmach o miastach przykłady "archiwologii” jako procesu prowadzenia wykopalisk i zapamiętywania, co pozwala na uchwycenie wielowymiarowego obrazu miasta (taż, Archiveology: Walter Benjamin and Archival Film Practices, Duke University Press, Durham 2018, s. 59).

${ }^{24}$ C. Childs, Representations of a Colonial Past in Contemporary Korean Cinema, "Asian Cinema" 2012, t. 23, nr 1, s. 59-74.

${ }^{25}$ Zwrot w ocenie kolonialnej przeszłości zapowiadały artykuły opublikowane w tomie Colonial Modernity in Korea, red. G. Shin, M. Robinson, Harvard University Press, Cambridge 1999. Warto zwrócić uwagę na kilka filmów nostalgicznych, które rozgrywają się w kolonialnym Seulu, ale w mniejszym stopniu opowiadają o walce narodowowyzwoleńczej, w większym zaś o narodzinach kultury masowej, jak dwie komedie: Dni radia (Raduio Deijeu, reż. Ha Ki-ho, 2007), Miłość i kłamstwa (Hae-eohwa, reż. Park Heung-sik, 2016).

${ }^{26}$ Motyw „nowoczesnych dziewczyn” pojawił się już w kinie przedwojennym, o czym świadczy film Marzenie (Mimong, reż. Yang Ju-nam, 1936), opowiadający o znudzonej żonie, która pewnego dnia wychodzi z domu, by skorzystać z uroków życia w Seulu. Kobieta udaje się na zakupy do domu towarowego, nocuje w hotelu, odwiedza modne kluby, flirtuje $\mathrm{z}$ nieznajomymi mężczyznami, pobiera lekcje tańca. Z dzisiejszej perspektywy główną atrakcją są obrazy tętniącego życiem miasta, sprawiające wrażenie autentycznego dokumentu epoki, w którym dominują oznaki nowoczesności.

27 Por. Y. M. Hwang, South Korean Historical Drama: Gender, Nation and the Heritage Industry, University of St Andrews 2011, s. 302 (nieopublikowana rozprawa doktorska).

${ }^{28}$ H. Ch'oe, A Symbol of Decadence: The Great Debate on Modern Girl, Modern Boy, w: New Women in Colonial Korea, red. H. Choi, Routledge, New York - London, s. 78-79.

${ }^{29}$ Podobne postaci, będące wytworem projektu asymilacyjnego, pojawiają się również w innych filmach. W Dniach radia mamy piosenkarkę Haruko/Choon-ja, która swobodnie łączy tożsamość japońską i koreańską, występuje zarówno w stroju gejszy, jak i w tradycyjnym kostiumie koreańskim. Płynna granica między różnymi tożsamościami podważa opozycję binarną.

${ }^{30} \mathrm{~W}$ finale bohaterowie zostają wezwani przed oblicze cesarza Gojonga, zmuszonego do abdykacji w 1910 r., który prosi bohaterów o odnalezienie „skradzionego listu”, czyli dokumentu, który mieli odczytać jego specjalni wysłannicy na konferencji pokojowej w Hadze, oraz dostarczenie go przywód- 
com państw europejskich. W ten sposób zakończenie filmu otwiera możliwość alternatywnej historii.

${ }^{31}$ Z kolei w Zabójstwie do strzelaniny dochodzi w domu towarowym Mitsukoshi.

${ }^{32}$ Wstawki współczesne pojawiają się między innymi w komedii Drużyna bejsbolowa (YMCA Yagudan, reż. Kim Hyun-seon, 2002), z kolei w Dniach radia mamy przejście od ujęć czarno-białych do kolorowych.

${ }^{33}$ J. Derrida, Widma Marksa, tłum. T. Załuski, PWN, Warszawa 2016, s. 163.

${ }^{34}$ Budynek szpitalny - jako typowy wytwór architektury kolonialnej - pojawił się również w innym horrorze, Uciszone (Gyeongseong haggyo: Sarajin sonyeodeul, reż. Lee Hae-young, 2015), którego akcja rozgrywa się w sanatorium dla dziewcząt, gdzie japońscy lekarze przeprowadzają eksperymenty medyczne.

${ }^{35}$ Wyrażenie furei senjin jest zapewne zmienioną formą japońskiego określenia futei senjin, które stosowano $\mathrm{w}$ odniesieniu do zbuntowanych lub też niezadowolonych Koreańczyków. Por. D. L. Nguyen, Alternate Histories of Korean National Sovereignty in "2009: Lost Memories", "Science Fiction Studies" 2017, t. 44, s. 560.

36 Stela Gwanggaeto to jeden z najstarszych koreańskich zabytków pisanych. Granitowy blok skalny o wysokości siedmiu metrów został wzniesiony w 414 r. przez Changsu, syna Gwanggaeto Wielkiego. Stela jest pokryta inskrypcją w języku chińskim, która opisuje dzieje panowania najwybitniejszego władcy z dynastii Goguryeo. Warto zaznaczyć, że Japończycy rozpoczęli intensywne prace archeologiczne niedługo po formalnej aneksji Korei, a w 1916 r. uchwalili ustawę o ochronie zabytków i powołali specjalny komitet.

${ }^{37}$ B. Stora, La guerre des mémoires: la France face à son passé colonial (entretiens avec Thierry Leclere), Éditions de l'Aube, La Tour d'Aigues 2007.

${ }^{38}$ Por. K. F. Sun, "Breaking the Dam to Reunify our Country": Alternate Histories of the Korean War in Contemporary South Korean Cinema, "International Journal of Korean History" 2015, t. 20, nr 2, s. 105.

39 Więcej na temat brytyjskiego kina dziedzictwa pisze Andrew Higson w książce English Heritage, English Cinema: Costume Drama Since 1980, Oxford University Press, Oxford 2003.

${ }^{40}$ Zamach zostaje udaremniony i członkowie oddziału dowodzonego przez Ahn Okyun (Jun Ji-hyun) przystępują do realizacji alternatywnego planu - ataku podczas przyjęcia weselnego syna Kawaguchiego.

${ }^{41}$ Jak pisze Kyoung-lae Kang: Zdjęcie jest dowodem na to, że taka przyszłośćlprzeszłość jest możliwa. Pozwala widzom spojrzeć na nieistniejący świat oraz sugeruje wyjście poza manichejski podział na "my" $i$ "oni”. Por. K. Kang, Kyung-Sung: Cinematic Memories of the Colonial Past in Contemporary Korea, "Camera Obscura" 2015, t. 30, nr 3, s. 28-29.

42 Por. J. An, Through the Prism of Masquerade: The Colonial Past in "Assassination", "International Journal of Korean History" 2016, t. 21 , nr 2, s. 203 .

\section{Krzysztof Loska}

Profesor zwyczajny na Uniwersytecie Jagiellońskim, dyrektor Instytutu Sztuk Audiowizualnych tejże uczelni, wiceprezes Polskiego Towarzystwa Badań nad Filmem i Mediami; zajmuje się historią filmu, zwłaszcza kinem azjatyckim. Autor stu pięćdziesięciu artykułów naukowych (publikowanych w „Kwartalniku Filmowym”, „Studiach Filmoznawczych”, „Przeglądzie Kulturoznawczym”, „Ekranach”, „Kulturze Współczesnej”, „Ethosie” i in.) oraz dwunastu książek, m.in. Dziedzictwo McLuhana - między nowoczesnościa a ponowoczesnościa (2001), Hitchcock: autor wośród gatunków (2002), David Cronenberg: rozpad ciała, rozpad gatunku (2003, wspólnie z A. Pitrusem), Tożsamość i media. O filmach Atoma Egoyana (2006), Poetyka filmu japonskiego (2009), Kenji Mizoguchi i đoyobraźnia melodramatyczna (2012), Nowy film japoński (2013), Mistrzowie kina japonskiego (2015), Postkolonialna Europa. Etnoobrazy wospótczesnego kina (2016). 


\section{Bibliografia}

An, J. (2016). Through the Prism of Masquerade: The Colonial Past in „Assassination”. International Journal of Korean History, 21 (2), ss. 193-204. https://doi.org/10.22372/ijkh.2016.08.21.2.193

Bastéa, E. (2004). Introduction. W: E. Bastéa (red.), Memory and Architecture (ss. 1-22). Albuquerque: University of New Mexico Press.

Benjamin, W. (1996). Dzieło sztuki w dobie reprodukcji technicznej (tłum. J. Sikorski). W: W. Benjamin, Anioł historii (ss. 201-231). Poznań: Wydawnictwo Poznańskie.

Benjamin, W. (2011). Ulica jednokierunkowa (tłum. B. Baran). Warszawa: Wydawnictwo Aletheia.

Benjamin, W. (2012). O kilku motywach u Baudelaire'a. W: W. Benjamin, Konstelacje. Wybór tekstów (tłum. A. Lipszyc, A. Wołkowicz) (ss. 263-310). Kraków: Wydawnictwo Uniwersytetu Jagiellońskiego.

Boym, S. (2001). The Future of Nostalgia. New York: Basic Books.

Bruno, G. (2018). Atlas of Emotion: Journeys in Art, Architecture, and Film. London - New York: Verso.

Ch'oe, H. (2013). A Symbol of Decadence: The Great Debate on Modern Girl, Modern Boy. W: H. Choi (red.), New Women in Colonial Korea (ss. 78-80). New York - London: Routledge.

Childs, C. (2012). Representations of a Colonial Past in Contemporary Korean Cinema. Asian Cinema, 23 (1), ss. 59-74. https://doi.org/10.1386/ac.23.1.59_1

Chŏng, I. (2013). Architecture and Urbanism in Modern Korea. Honolulu: University of Hawai'i Press.

Cumings, B. (2005). Korea's Place in the Sun: A Modern History. New York - London: Norton.

Eco, U. (1986). Architecture and Memory. VIA, 8, ss. 88-94.

Holmes, A. (2017). Politics of Architecture in Contemporary Argentine Cinema. London: Palgrave Macmillan.

Hsia, C. (2002). Theorizing Colonial Architecture and Urbanism: Building Colonial Modernity in Taiwan. Inter-Asia Cultural Studies, 3 (1), ss. 7-23. https://doi.org/10.1080/14649370220135788

Hwang, Y. M. (2011.) South Korean Historical Drama: Gender, Nation and the Heritage Industry. St Andrews: University of St Andrews (niepublikowana rozprawa doktorska).

Kang, K. (2015). Kyung-Sung: Cinematic Memories of the Colonial Past in Contemporary Korea. Camera Obscura, 30 (3), ss. 27-59. https://doi.org/10.1215/02705346-3160641

Kim, S. (2009). Re-locating the National: Spatialization of the National Past in Seoul. Policy Futures in Education, 7 (2), ss. 256-265. https://doi.org/10.2304/pfie.2009.7.2.256

Kołakowski, L. (1989). Główne nurty marksizmu. Część III: Rozkład. Warszawa: Wydawnictwo Krąg.

Loska, K. (2014). Czas utracony - nostalgia i trauma w postkolonialnym filmie francuskim. Kwartalnik Filmowy, 86, ss. 92-103.

Metcalf, T. R. (1989). An Imperial Vision: Indian Architecture and Britain's Raj. Berkeley: University of California Press.

Nguyen, D. L. (2017). Alternate Histories of Korean National Sovereignty in „2009: Lost Memories". Science Fiction Studies, 44, ss. 546-562. https://doi.org/10.5621/sciefictstud.44.3.0546

Nishizawa, Y. (2016). A Study of Japanese Colonial Architecture in East Asia. W: I. Kuroishi (red.), Constructing the Colonized Land: Entwined Perspectives of East Asia around WW II (ss. 11-30). London: Routledge.

Pabjan, B., Czajkowski, P. (2015). Pamięć zbiorowa a przestrzeń miasta. Forum Socjologiczne, 6, ss. 9-19.

Rurarz, J. (2009). Historia Korei. Warszawa: Wydawnictwo Akademickie Dialog.

Russell, C. (2018). Archiveology: Walter Benjamin and Archival Film Practices. Durham: Duke University Press.

Smith, K. M. (2017). Vicarious Politics: Violence and the Colonial Period in Contemporary South Korean Film. The Asia-Pacific Journal, 15 (3), ss. 1-25.

Stora, B. (2007). La guerre des mémoires: la France face à son passé colonial (entretiens avec Thierry Leclere). La Tour-d'Aigues: Éditions de l'Aube.

Sun, K. F. (2015). Breaking the Dam to Reunify our Country: Alternate Histories of the Korean War in Contemporary South Korean Cinema. International Journal of Korean History, 20 (2), ss. 85-120. https://doi.org/10.22372/ijkh.2015.20.2.85 
Vidler, A. (2000). Warped Space: Art, Architecture, and Anxiety in Modern Culture. Cambridge: The MIT Press.

Włodek, P. (2018). Kres niewinności. Obraz i upamiętnienie ery Eisenhowera w amerykańskich filmach $i$ serialach - pomiędzy reprezentacja, nostalgia a krytycznym retro. Kraków: Wydawnictwo Uniwersytetu Pedagogicznego.

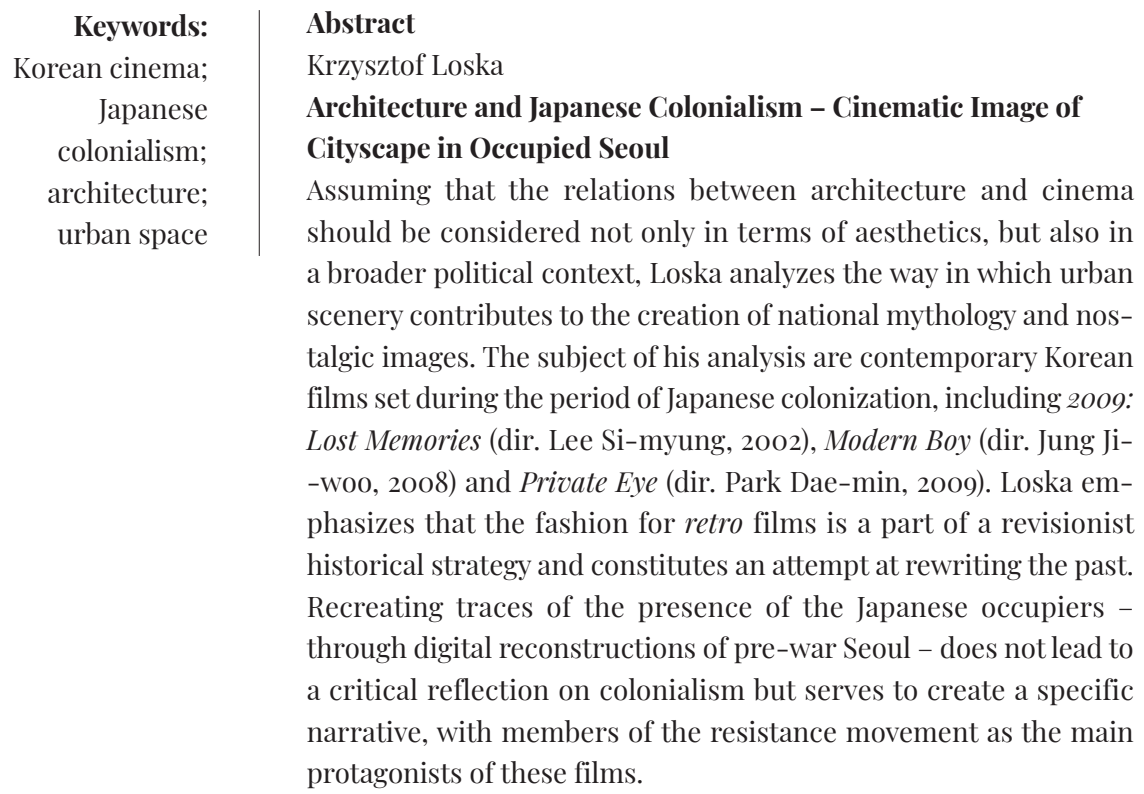

